\title{
Characterization, antioxidant, ACE inhibition and toxicity evaluations of palm kernel cake-derived Alcalase ${ }^{\circledR}$ hydrolysate
}

\author{
Khar-Ling NG ${ }^{1}$, Yen-Nee TAN ${ }^{2,3}$ (D), Md. Anuar OSMAN ${ }^{1}$, Nor Fadilah RAJAB ${ }^{4}$, Kah-Yaw EE ${ }^{2,3 *}$
}

\begin{abstract}
Palm (Elaeis guineensis Jacquin) kernel cake protein (PKCP) was extracted and hydrolyzed using Alcalase ${ }^{\circledR} 2.4 \mathrm{~L}$ to obtain hydrolysate $(\mathrm{PKCPH})$, then fractionated using size exclusion chromatography. PKCPH consisted of predominantly fraction one (PKCPH1), containing two peptides $(4.9 \mathrm{kDa}$ and $6.3 \mathrm{kDa})$ with functional amide (6.75-7.04 ppm) and amine (1.5-2.0 ppm) groups. PKCP and PKCPH shared similar amino acid profiles. PKCPH1 had moderate amounts of hydrophobic (23.60\%) and antioxidant (26.10\%) amino acids, with high hydrophobicity index $\left(\mathrm{H}_{0} 79.60\right)$, thus exhibiting the highest antioxidant activity in mostly all the antioxidant assays. On the other hand, fraction two, PKCPH2 $(58.8 \mathrm{kDa})$, possessed strong angiotensin converting enzyme (ACE) inhibitory activity (77.29\%), but undetectable antioxidant activity. Furthermore, high viability (87-92\%) and negligible cytotoxic activity were revealed with the highest dosages of PKCPH $(2 \mathrm{mg} / \mathrm{mL})$ and PKCPH1 $(1 \mathrm{mg} / \mathrm{mL}) \mathrm{in}$ 3-(4,5-dimethylthiazol-2-yl)-2,5-diphenyltetrazolium bromide (MTT), Salmonella reverse mutation (AMES), alkaline comet and micronucleus $(\mathrm{MNi})$ assays. Besides, in vivo acute oral toxicity test on $\mathrm{PKCPH}$ using Sprague Dawley albino rats showed negative outcome according to the consistent body and organ weights as well as normal morbidity. In short, PKCPH is safe for potential applications in the formulation of functional food and nutraceutical products with health benefits.
\end{abstract}

Keywords: protein hydrolysate; characterization; antioxidant; ACE inhibition; toxicity analyses.

Practical Application: Characterization, bioactivity and toxicity studies of palm kernel cake protein hydrolysate.

\section{Introduction}

Palm (Elaeis guineensis Jacq.) oil milling industry is one of the major contributors of Malaysian agriculture sector and gross domestic product. Palm oil production speeds up in recent years and devotes about $36 \%$ of the global edible vegetable oil. The annual global consumption of palm oil is estimated to be 73 million metric tons (Ritchie \& Roser, 2021). The growing production of palm oil indicates the increasing production of agricultural wastes or by-products, such as empty fruit bunch (EFB), palm oil milling effluent (POME) and palm kernel cake (PKC). Recycling EFB and POME for the production of sustainable biofuel and bioenergy has been a notable research topic recently in order to lessen negative impacts on the environment (Kaniapan et al., 2021). PKC is a by-product of screw press expeller and usually it has low market value due to underutilization. In Malaysia, approximately 2.4 million metric tons of PKC are produced by palm oil millers every year (Malaysian Oil Palm Statistics, 2021). Part of the processed PKC is commonly used as animal feed in broiler and ruminant farming industries, or fertilizer and soil conditioner, but majority of it is discarded as industrial waste or landfilled (Halim et al., 2017; Ishak et al., 2019). It has been reported that approximately $76 \%$ of the total digestible nutrients are retained in PKC after the expelling process, which consisting of $16-20 \%$ of protein (Alimon, 2006; Kum \& Zahari, 2011). According to a previous study (Ng \& Mohd Khan, 2012), extractability of palm kernel cake protein was optimized using an alkaline extraction technique or $\mathrm{pH}$ shift method and achieved up to $68.50 \%$ mass of the total soluble matter. This substantial amount of extractable protein in PKC could be one of the potential sources of plant-based protein.

A recent study of $\mathrm{Ng}$ et al. (2013) reported that palm kernel cake protein (PKCP) showed potential antioxidant activity. As greater health awareness arises among consumers on the risks of using synthetic antioxidants in supplements and food products, more attention has been placed on the search of natural antioxidants (Xu et al., 2017). Plant-derived antioxidant peptides are generally isolated from protein hydrolysate through enzymatic hydrolysis using single (Liang et al., 2020; Zhang et al., 2019) or various proteases (Sheng et al., 2019), sequential hydrolysis or simulated gastrointestinal digestion (Feng, et al., 2019) and fermentation (Jiang et al., 2019; Wu, et al., 2018). With the aid of bioassay-guided approaches, the antioxidant peptides can be purified by using chromatography or non-chromatography methods, followed by characterization of amino acid components and molecular weights, as well as peptide sequencing with chromatography- 
tandem mass spectrometry and Edman degradation methods (Liang et al., 2020). Many studies of different agro-wastes, such as rapeseed meal (Aider \& Barbana, 2011), pumpkin oil cake (Vastag et al., 2010), cottonseed meal (Liadakis et al., 1993), and soybean cake (Wu et al., 1998), applied similar aforementioned strategies to reveal bioactive peptides. They may contain low molecular weight proteins and fragments of peptide with various sizes (Nasri, 2017). Generally, those hydrolysates which consisting of high numbers of peptide with 2-20 amino acid residues and low molecular weight $(<6 \mathrm{kDa})$ possess potent bioactivities (Chai et al., 2021). The antioxidant potentials are partly attributed to the extensive amounts of hydrophobic and aromatic amino acid residues (Sun et al., 2019). In vitro free radical scavenging assays are usually incorporated in the process of bioactive peptide isolation. The bioactive properties of peptides are then further analyzed by using cellular models, for example, human cell lines, including hepatocarcinoma (HepG2) cells (Zhou et al., 2020; Yang et al., 2017), Chang liver cells (Liang et al., 2020), intestinal Caco-2 cells (García-Nebot et al., 2014; Zhang et al., 2019) and neuroblastoma (SH-SY5Y) cells (Sheng et al., 2019). Hydrogen peroxide $\left(\mathrm{H}_{2} \mathrm{O}_{2}\right)$ and 2,2'-azobis(2-amidinopropane) dihydrochloride $(\mathrm{AAPH})$ are commonly used as oxidative stress substances (Liang et al., 2020; Jiang et al., 2019; Yang et al., 2017).

Furthermore, diversified peptide structures with cationic amino acids make possible the development of multifunctional properties (Chai et al., 2021). Other than antioxidant activity, antihypertensive activity was also reported in some food-derived protein hydrolysates or peptides, such as rice (Chen et al., 2013), soybean (Gibbs et al., 2004) and chickpea (Yust et al., 2003). Nevertheless, the association of potential genotoxic properties with high concentration of natural bioactive compounds from edible plants was reported in a study of Wan-Ibrahim et al. (2010). Although effective valorization can transform PKCP into many useful products, possible cytotoxic and oral toxicity effects of a novel PKCP hydrolysate should be evaluated. Therefore, this study was conducted to extract PKCP, produce its hydrolysate (PKCPH) using enzyme Alcalase ${ }^{\circledR} 2.4 \mathrm{~L}$ and partially fractionate the hydrolysate using size exclusion chromatography. Samples were characterized using the Agilent 2100 Bioanalyzer system, reverse phase-high performance liquid chromatography (RP-HPLC) and nuclear magnetic resonance (NMR) spectroscopy, followed by evaluation studies on their antioxidant, angiotensin converting enzyme (ACE) inhibition, cytotoxicity and acute oral toxicity properties.

\section{Materials and methods}

\subsection{Materials}

Palm kernel cake (PKC) was sourced from FGV Kernel Products Sdn. Bhd., Malaysia. PKC was pulverized into $0.2 \mathrm{~mm}$ mesh powder. All chemicals and reagents were of analytical grade and purchased from Sigma Aldrich, Denmark; Cayman Chemical, USA; Merck, Germany; and Fisher Scientific, Malaysia; unless stated otherwise.

\subsection{Protein isolation and hydrolysis}

Protein was isolated from PKC using pH-shift method (Marmon \& Undeland, 2013). Briefly, pH of the sample mixture in 10 -volume of distilled water was adjusted to $\mathrm{pH} 11$ using $2 \mathrm{M} \mathrm{NaOH}$ solution and shaken constantly in a water bath at $50{ }^{\circ} \mathrm{C}$ for $30 \mathrm{~min}$. After that, the mixture was centrifuged (4000 rpm) for $10 \mathrm{~min}$ to collect the supernatant, followed by precipitation at $\mathrm{pH} 4$ using $2 \mathrm{M} \mathrm{HCl}$. The mixture was pelleted at $10000 \mathrm{rpm}$ for $10 \mathrm{~min}$, the pellet was mixed with minimal amount of distilled water and neutralized. Finally, the resulting palm kernel cake protein (PKCP) was freeze dried (Scanvac Labogene Coolsafe, Denmark). The lyophilized PKCP was then subjected to enzymatic hydrolysis using Alcalase ${ }^{\circledR} 2.4 \mathrm{~L}$ ( $\geq 2.4 \mathrm{U} / \mathrm{g}, \mathrm{EC} 3.4 .21 .62, \mathrm{P} 4860$ ) according to the procedure of $\mathrm{Ng}$ et al. (2013). PKCP (0.1g) was firstly reconstituted in $10 \mathrm{~mL}$ of $0.1 \mathrm{M}$ phosphate buffer $(\mathrm{pH} 8.5)$, followed by mixing with $1 \mu \mathrm{L}$ of Alcalase ${ }^{\circledR}$. The mixture was incubated in a water bath shaker at $51.5^{\circ} \mathrm{C}$ for $60 \mathrm{~min}$, then the hydrolysis was terminated by thermic shock $\left(100{ }^{\circ} \mathrm{C}, 10 \mathrm{~min}\right)$. After centrifugation at $4000 \mathrm{rpm}$ for $10 \mathrm{~min}$, palm kernel cake protein hydrolysate $(\mathrm{PKCPH})$ was collected and freeze dried.

\subsection{Fractionation of $\mathrm{PKCPH}$}

A total of $4 \%(\mathrm{w} / \mathrm{v}) \mathrm{PKCPH}$ was prepared in $1 \mathrm{mM}$ phosphate-buffered saline (PBS) solution at $\mathrm{pH} 7$ and injected onto a HiPrep ${ }^{\mathrm{TM}}$ 26/60 Sephacryl S-100 HR column with AKTA Prime Plus System (GE Healthcare, USA). The separation process was conducted at room temperature, $1.3 \mathrm{~mL} / \mathrm{min}$ flow rate, 0.15 MPa pressure, and monitored at $280 \mathrm{~nm}$. The resulted fractions were freeze dried prior to analysis.

\subsection{Determination of amino acids}

According to the procedure of Galdón et al. (2010), $30 \mathrm{mg}$ of sample were hydrolyzed at $110^{\circ} \mathrm{C}$ for $24 \mathrm{~h}$ with $1 \mathrm{~mL}$ of $6 \mathrm{M} \mathrm{HCl}$ in a Pyrex glass tube fitted with Teflon-lined screw cap. The hydrolysate was then filtered through a $0.45 \mu \mathrm{m}$ filter GHP (Waters, USA) and an aliquot of $100 \mu \mathrm{L}$ was evaporated to dryness under vacuum. The dried sample was reconstituted with $20 \mu \mathrm{L} \mathrm{HCl}(20 \mathrm{mM})$ that contained $2.5 \mathrm{mM}$ internal standard L-a-amino-n-butyric acid. Derivatization was carried out using AccQ-Fluor Reagent Kit (Waters, USA). Briefly, $20 \mu \mathrm{L}$ of sample solution were mixed with $20 \mu \mathrm{L}$ of AccQ-Fluor Reagent and $60 \mu \mathrm{L}$ of $200 \mathrm{mM}$ borate buffer, then incubated at $55^{\circ} \mathrm{C}$ for $10 \mathrm{~min}$. For positive control, $10 \mu \mathrm{L}$ of amino acid hydrolysate standard were used to replace the sample. Next, $10 \mu \mathrm{L}$ of sample or $5 \mu \mathrm{L}$ of standard solutions were injected into a reverse phase-high performance liquid chromatography (RP-HPLC) system. The gradient separation was carried out using a $60 \AA, 3.9 \times 150 \mathrm{~mm}$ AccQ-Tag column (Waters, USA) at $37^{\circ} \mathrm{C}$ and $1.0 \mathrm{~mL} / \mathrm{min}$ flow rate, with acetate-phosphate buffer as eluent $\mathrm{A}$, acetonitrile and Milli- $Q$ water as eluents $B$ and $C$, respectively. The elution was monitored at $0 \min (100 \% \mathrm{~A}), 0.5 \mathrm{~min}(99 \% \mathrm{~A}$ and $1 \% \mathrm{~B})$, $18 \mathrm{~min}(95 \% \mathrm{~A}$ and $5 \% \mathrm{~B}), 19 \mathrm{~min}(91 \% \mathrm{~A}$ and $9 \% \mathrm{~B}), 29.5 \mathrm{~min}$ (83\% A and $17 \% \mathrm{~B}), 33 \mathrm{~min}(60 \% \mathrm{~B}$ and $40 \% \mathrm{C})$, and $36 \mathrm{~min}$ $(100 \% \mathrm{~A})$. The amino acid-AQC derivatives were detected with fluorescence upon excitation at $250 \mathrm{~nm}$ and emission at $395 \mathrm{~nm}$. 
The peaks in chromatogram were identified according to the retention time of standard.

\subsection{Determination of molecular weight}

$\mathrm{PKCPH}$ and its fractions were characterized using the Agilent Protein 80 kit with the Agilent 2100 Bioanalyzer system (Agilent Technologies, USA). A standard protein ladder (1.6-95.0 kDa) was applied. Sample buffer and other reagents were prepared according to the Expert User's Guide at http://www.agilent.com. Data were analyzed with the provided software (ver. B.02.02).

\subsection{Determination of surface hydrophobicity}

An aliquot $(20 \mu \mathrm{L})$ of 1-anilino-8-naphthalene-sulfonate solution ( $8.0 \mathrm{mM}$ in $0.01 \mathrm{M}$ phosphate buffer, $\mathrm{pH} 7$ ) was added to $4 \mathrm{~mL}$ of sample solution $(0.0001-0.005 \% \mathrm{w} / \mathrm{v}$ in $0.01 \mathrm{M}$ phosphate buffer, $\mathrm{pH} 7$ ). Fluorescence intensity was read at $365 \mathrm{~nm}$ excitation and $484 \mathrm{~nm}$ emission wavelengths using a F-7000 fluorescent spectrophotometer (Hitachi Co., Japan). Hydrophobicity index $\left(\mathrm{H}_{\mathrm{o}}\right)$ is defined in a plot of initial gradient of the intensity versus sample concentrations (Alizadeh-Pasdar \& Li-Chan, 2000).

\subsection{Nuclear magnetic resonance (NMR) spectroscopy analysis}

PKCPH1 (5 mg) was dissolved in $600 \mu \mathrm{L}$ of deuterium oxide and transferred into a $5 \mathrm{~mm}$ NMR tube. The relative sample spectra of ${ }^{1} \mathrm{H}$ and ${ }^{13} \mathrm{C}$ isotopes were analyzed using a $600 \mathrm{MHz}$ FT-NMR Bruker AV spectrometer equipped with a cryoprobe. For ${ }^{13} \mathrm{C}, 7168$ scans were performed in every $2 \mathrm{~s}$ at $200 \mathrm{ppm}$ spectra range.

\subsection{In vitro antioxidant activities}

Free radical scavenging activity of samples was analyzed using 2, 2-diphenyl-1-picrylhydrazl (DPPH), 2,2'-azino-bis(3ethylbenzothiazoline-6-sulfonic acid) (ABTS), superoxide anion $\left(\mathrm{O}_{2}^{-}\right)$free radical scavenging and oxygen radical absorbing capacity (ORAC) assays with slight modification (Ee et al., 2012, 2019).

For DPPH assay, $500 \mu \mathrm{L}$ of sample $(25-1000 \mu \mathrm{g} / \mathrm{mL}$ in distilled water) or Trolox ${ }^{\circledR}$ solution $(1-120 \mu \mathrm{M})$ were mixed with $500 \mu \mathrm{L}$ of $0.15 \mathrm{mM}$ DPPH solution in $80 \%$ (v/v) methanol and incubated at room temperature $\left(25^{\circ} \mathrm{C}\right)$ in dark for $30 \mathrm{~min}$. The absorbance $(A)$ of the mixture was measured at $517 \mathrm{~nm}$ using a spectrophotometer (Shimadzu UV-2450, Japan). $\mathrm{EC}_{50}$ values were determined. For ABTS assay, $80 \mu \mathrm{L}$ of sample $(50-1000 \mu \mathrm{g} / \mathrm{mL}$ in distilled water) or Trolox ${ }^{\circledR}$ solution $(1-120 \mu \mathrm{M})$ were mixed with $1 \mathrm{~mL}$ of pre-prepared ABTS working solution with $0.70 \pm$ 0.02 absorbance at $734 \mathrm{~nm}$. The mixture was incubated at room temperature for $5 \mathrm{~min}$ before reading absorbance at $734 \mathrm{~nm}$. For ORAC assay, $300 \mu \mathrm{L}$ of sample $(50-1000 \mu \mathrm{g} / \mathrm{mL}$ in distilled water) or Trolox ${ }^{\circledR}$ solution $(1-120 \mu \mathrm{M})$ were mixed with $300 \mu \mathrm{L}$ of $0.6 \mathrm{M} \mathrm{AAPH}$ and $2.4 \mathrm{~mL}$ of $81.6 \mathrm{nM}$ fluorescein solution in $75 \mathrm{mM}$ PBS (pH 7.4). Fluorescence readings were recorded in every minute using a F-7000 florescence spectrophotometer at $493 \mathrm{~nm}$ excitation and $515 \mathrm{~nm}$ emission wavelengths until all readings achieved less than $5 \%$ of the initial reading. For superoxide anion free radical scavenging (SAFRC) assay, $100 \mu \mathrm{L}$ of sample $(1 \mathrm{mg} / \mathrm{mL}$ in $50 \mathrm{mM}$ phosphate buffer, $\mathrm{pH}$ 7.4) or ascorbic acid solution were mixed with $200 \mu \mathrm{L}$ of $0.34 \mathrm{mM}$ nitro blue tetrazolium solution and $500 \mu \mathrm{L}$ of $2 \mathrm{mM}$ hypoxanthine solution, then reacted with $200 \mu \mathrm{L}$ of $0.56 \mathrm{U} / \mathrm{mL}$ xanthine oxidase. The mixture was vortexed for $30 \mathrm{~s}$ before reading absorbance in every minute for $10 \mathrm{~min}$. The inhibition (\%) of free radicals was calculated using the Equation 1 below:

$\%$ inhibition $=\frac{\operatorname{Control}(A)-\operatorname{sample}(A)}{\operatorname{Control}(A)} \times 100 \%$

Reducing power of samples was analyzed using ferric reducing antioxidant power (FRAP) and ferrous ion chelating (FIC) assays (Ee et al., 2019). For FRAP assay, $200 \mu \mathrm{L}$ sample $\left(25-1000 \mu \mathrm{g} / \mathrm{mL}\right.$ in distilled water) or $\mathrm{FeSO}_{4}$ solution $(1-200 \mu \mathrm{M})$ were mixed with $1.8 \mathrm{~mL}$ of pre-warmed $\left(37^{\circ} \mathrm{C}\right)$ FRAP reagent, containing $10 \mathrm{mM}$ tripyridyltriazine solution in $40 \mathrm{mM} \mathrm{HCl}$, $20 \mathrm{mM} \mathrm{FeCl}_{3}$ and $0.3 \mathrm{M}$ acetate buffer (pH 3.6) at a ratio of 10:1:1. After incubation for $5 \mathrm{~min}$, the absorbance was read at $593 \mathrm{~nm}$. For FIC assay, $200 \mu \mathrm{L}$ of sample $(25-1000 \mu \mathrm{mol} / \mathrm{L})$ or ethylenediaminetetraacetic acid (EDTA) solution were mixed with $100 \mu \mathrm{L}$ of $2 \mathrm{mM} \mathrm{FeCl}_{2}$ solution in distilled water with final volume of $5 \mathrm{~mL}$. The mixture was left at room temperature for $5 \mathrm{~min}$, then mixed with $200 \mu \mathrm{L}$ of $5 \mathrm{mM}$ ferrozine solution. The absorbance was read at $562 \mathrm{~nm}$ after further incubation for $5 \mathrm{~min}$ in dark. Distilled water was assayed as negative control.

\subsection{In vitro anti-ACE activity}

Antihypertensive activities of PKCP, $\mathrm{PKCPH} 1$ and $\mathrm{PKCPH} 2$ were determined using angiotensin converting enzyme (ACE) inhibition assay (Cushman \& Cheung, 1971). For each assay, $75 \mu \mathrm{L}$ of sample $(1 \mathrm{mg} / \mathrm{mL})$ or captopril $(1.5 \mathrm{ng} / \mathrm{mL})$ were mixed with $75 \mu \mathrm{L}$ of substrate N-Hippuryl-His-Leu (15 mM HHL in $100 \mathrm{mM}$ sodium borate buffer, $\mathrm{pH} 8.3$, containing $300 \mathrm{mM} \mathrm{NaCl}$ ). The mixture was pre-incubated at $37^{\circ} \mathrm{C}$ for $10 \mathrm{~min}$ before adding $75 \mu \mathrm{L}$ of ACE solution $(8 \mathrm{mU} / \mathrm{mL})$. After incubation for $30 \mathrm{~min}$, the reaction was terminated with $250 \mu \mathrm{L}$ of $1.0 \mathrm{~N} \mathrm{HCl}$ solution, filtered through $0.22 \mu \mathrm{m}$ nylon membrane filter, followed by RP-HPLC analysis. Ten microliters of the filtrate were injected onto a Symmetry C18 column, $5 \mu \mathrm{m}, 4.6 \times 250 \mathrm{~mm}$ (Waters, USA), eluted at $0.8 \mathrm{~mL} / \mathrm{min}$ flow rate using a mobile phase composed of $50 \%(\mathrm{v} / \mathrm{v})$ methanol and $0.1 \%$ trifluoroacetic acid. The absorbance $(A)$ of hippuric acid was read at $228 \mathrm{~nm}$. The inhibition (\%) of ACE was calculated using the Equation 2 below:

$\%$ Inhibition $=\frac{\operatorname{Control}(A)-\operatorname{sample}(A)}{\operatorname{Control}(A)} \times 100 \%$

\subsection{In vitro cytotoxicity and cell viability}

The mutagenicity potential of PKCPH was evaluated using the Salmonella reverse mutation assay (AMES assay) (Maron \& Ames, 1983). Salmonella Typhimurium strains TA98 and TA100 were cultured in nutrient broth at $37^{\circ} \mathrm{C}$ overnight. Bacterial culture $\left(0.05 \mathrm{~mL}, \approx 10^{8}\right.$ bacteria) was mixed with $0.05 \mathrm{~mL}$ of $\mathrm{PKCPH}(2 \mathrm{mg} /$ plate in $0.15 \mathrm{M} \mathrm{NaCl}$ solution) and $0.5 \mathrm{~mL}$ of 
rat liver homogenate $(S 9,9000 \times \mathrm{g}$ microsomal fraction of $1 \mathrm{~g}$ wet tissue in $3 \mathrm{~mL}$ of $\mathrm{NaCl}$ solution), then added into $2 \mathrm{~mL}$ of molten top agar. The mixture was poured on glucose minimal agar plates and incubated at $37{ }^{\circ} \mathrm{C}$ for $48 \mathrm{~h}$. Sodium azide (5 $\mu \mathrm{g} /$ plate), 4 -nitro-o-phenylenediamine $(2.5 \mu \mathrm{g} /$ plate $)$ and 2 -aminoanthracene $(0.5-1 \mu \mathrm{g} /$ plate $)$ were assayed as positive controls. Mutagenicity was evaluated by comparing the number of revertant colonies in the samples with the negative control (0.15 M NaCl).

The clastogenic and aneugenic effects of PKCPH were evaluated through determining the formation of small chromosomal fragments or micronuclei $(\mathrm{MNi})$ in the cytoplasm of interphrasing American Type Culture Collection (ATCC) V79-4 Chinese hamster lung cells. The cells were firstly incubated with $5 \mathrm{~mL}$ of $2 \mathrm{mg} / \mathrm{mL} \mathrm{PKCPH}$ in a $5 \% \mathrm{CO}_{2}$ incubator at $37{ }^{\circ} \mathrm{C}$ for $3 \mathrm{~h}$. Then, the supernatant was discarded and the cultures were washed and incubated in $5 \mathrm{~mL}$ of fetal bovine serum (FBS)supplemented medium for $24 \mathrm{~h}$. Cultures were harvested via trypsinization and pelleted at $1500 \mathrm{rpm}$ for $5 \mathrm{~min}$. The pelleted cells were then re-suspended in $2 \mathrm{~mL}$ of $0.075 \mathrm{M} \mathrm{KCl}$ solution and pelleted again. Subsequently, it was serially re-suspended in $5 \mathrm{~mL}$ of fresh Carnoy's solution and pelleted for three times. Finally, $2-3$ drops of cell suspension were placed on a $30 \mathrm{~cm}$ horizontal pre-warmed slide and left to air dry. The slides were stained with $20 \mu \mathrm{g} / \mathrm{mL}$ acridine orange solution and immediately mounted prior to the microscopic analysis. The scoring was carried out under a fluorescent microscope. Mitomycin $(0.3 \mathrm{mg} / \mathrm{mL})$ and growth medium were assayed as positive and negative controls, respectively.

Alkaline comet assay (Singh et al., 1988) was performed using cell line V79-4 that cultured in Gibco Dulbecco's Modified Eagle Medium (BRL, USA) with 10\% (v/v) FBS and 2 mM glutamine. The culture was firstly incubated with $1-2 \mathrm{mg} / \mathrm{mL}$ of $\mathrm{PKCPH}$ and PKCPH1, individually, in a $5 \% \mathrm{CO}_{2}$ incubator at $37{ }^{\circ} \mathrm{C}$ for $24 \mathrm{~h}$. Hydrogen peroxide $(0.1 \mathrm{mM})$ and growth medium were assayed as positive and negative controls, respectively. After incubation, cells were washed with PBS, dissociated via trypsinization, added with $1 \mathrm{~mL}$ of growth medium and then centrifuged $(2500 \mathrm{rpm})$ for $5 \mathrm{~min}$. The cells were collected and re-suspended in $80 \mu \mathrm{L}$ of $0.6 \%$ (w/v) low melting point agarose, spread on a frosted slide pre-coated with $130 \mu \mathrm{L}$ of $0.6 \%$ normal melting point agarose, then kept at $4{ }^{\circ} \mathrm{C}$ for $5 \mathrm{~min}$. After that, the slides were soaked in lysis buffer $(2.5 \mathrm{M} \mathrm{NaCl}, 10 \mathrm{mM}$ Tris, 10 mM EDTA, $1 \%$ Triton X-100 and 10\% DMSO, pH 10.0) at $4{ }^{\circ} \mathrm{C}$ for $1 \mathrm{~h}$ to remove cellular protein. Next, the slides were incubated in a horizontal electrophoresis unit with buffer $(300 \mathrm{mM} \mathrm{NaOH}$ and $1 \mathrm{mM}$ EDTA, $\mathrm{pH}>13$ ) for $20 \mathrm{~min}$ before electrophoresis (300 mA, $25 \mathrm{~V}, 20 \mathrm{~min})$. Finally, the excess alkaline on the slides was neutralized with Tris buffer $(0.4 \mathrm{M}, \mathrm{pH} 7.5)$, followed by staining with $45 \mu \mathrm{L}$ ethidium bromide and examining under a Leitz Dialux 20 fluorescence microscope equipped with a Ploemopak 2.3 illuminator. Tail moments were determined using the instrument software.

The effects of PKCPH and PKCPH1 on cell viability were tested using 3-(4,5-dimethylthiazol-2-yl)-2,5-diphenyltetrazolium bromide (MTT) assay (Mosmann, 1983). ATCC L-929 Mus musculus cells were incubated with $1-2 \mathrm{mg} / \mathrm{mL}$ of PKCPH and
PKCPH1, individually, in a $5 \% \mathrm{CO}_{2}$ incubator at $37^{\circ} \mathrm{C}$ for $24 \mathrm{~h}$. Menadione and growth medium were assayed as positive and negative controls, respectively. The incubation with MTT was carried out for $4 \mathrm{~h}$ before reading absorbance at $550 \mathrm{~nm}$.

\subsection{In vivo acute oral toxicity}

PKCPH was singly administered to a group of Sprague Dawley albino rats $(\mathrm{n}=10,190-290 \mathrm{~g})$ at an accredited laboratory, Makmal Bioserasi $^{\text {TM }}$ (MS ISO/IEC 17025:2005, SAMM 0479, OECD-GLP 008), Universiti Kebangsaan Malaysia, for 14 consecutive days, with 5 days of acclimatization period before commencing the experiment. The handling procedure and experimental design for the animal testing were conducted as per the guideline set by the National Institutes of Health (Guide for the Care and Use of Laboratory Animals). PKCPH was mixed in normal saline (25 mg/kg body weight) and fed through gastric intubation using a plastic gavage tube. Their morbidity, signs of toxicity and behavioral changes, as well as mortality were observed at $1 \mathrm{~h}$ and $3 \mathrm{~h}$ after dosing on the first day and once daily for 14 days. Their body weights were monitored weekly. Five rats were used as negative controls. Upon termination, all the rats were euthanized and necropsied.

\subsection{Statistical analysis}

All extractions and analyses were carried out at least in triplicate and the mean with standard deviation were reported. Where applicable, data were subjected to one-way analysis of variance (ANOVA) via SPSS 17.0 (IBM Corporation, US). Comparison of means was conducted using Duncan's multiple range test. Significant difference was reported at $p<0.05$.

\section{Results and discussion}

\subsection{Characterization of palm kernel cake protein and its hydrolysate}

Palm kernel cake protein was extracted ( $\mathrm{Ng} \&$ Mohd Khan, 2012) and hydrolyzed using Alcalase ${ }^{\circledR} 2.4 \mathrm{~L}$ enzyme, followed by partial fractionation using a HiPrep column. Result (Figure 1) revealed two hydrolysate fractions, a predominant PKCPH1 and a minimal PKCPH2, with distinctive molecular sizes. These two fractions were collected individually and further analyzed with the Agilent 2100 Bioanalyzer system. Figure 2 shows the molecular weight profiles of PKCPH and two fractions PKCPH1 and $\mathrm{PKCPH} 2$ in comparison with the protein marker. Results showed that the PKCPH composed of high concentration of peptides that were smaller than $7.1 \mathrm{kDa}$, and trace amounts of larger size proteins which were observed as tiny peaks in the chromatogram and a hazy smear in the gel-like image. Two peptides with different molecular weights, $4.9 \mathrm{kDa}$ and $6.3 \mathrm{kDa}$, were determined in PKCPH1, whereas PKCPH2 only contained one protein $(58.8 \mathrm{kDa})$. The relative concentrations of PKCPH1 (2730.30 ng/ $\mu \mathrm{L}$ and $2808.30 \mathrm{ng} / \mu \mathrm{L}$, respectively) and PKCPH2 $(11.90 \mathrm{ng} / \mu \mathrm{L})$ were also measured. Results indicated the effectiveness of size exclusion column chromatography in partial fractionation of $\mathrm{PKCPH}$. Visible peptide peaks and bands were then revealed using the Bioanalyzer system with the automated 


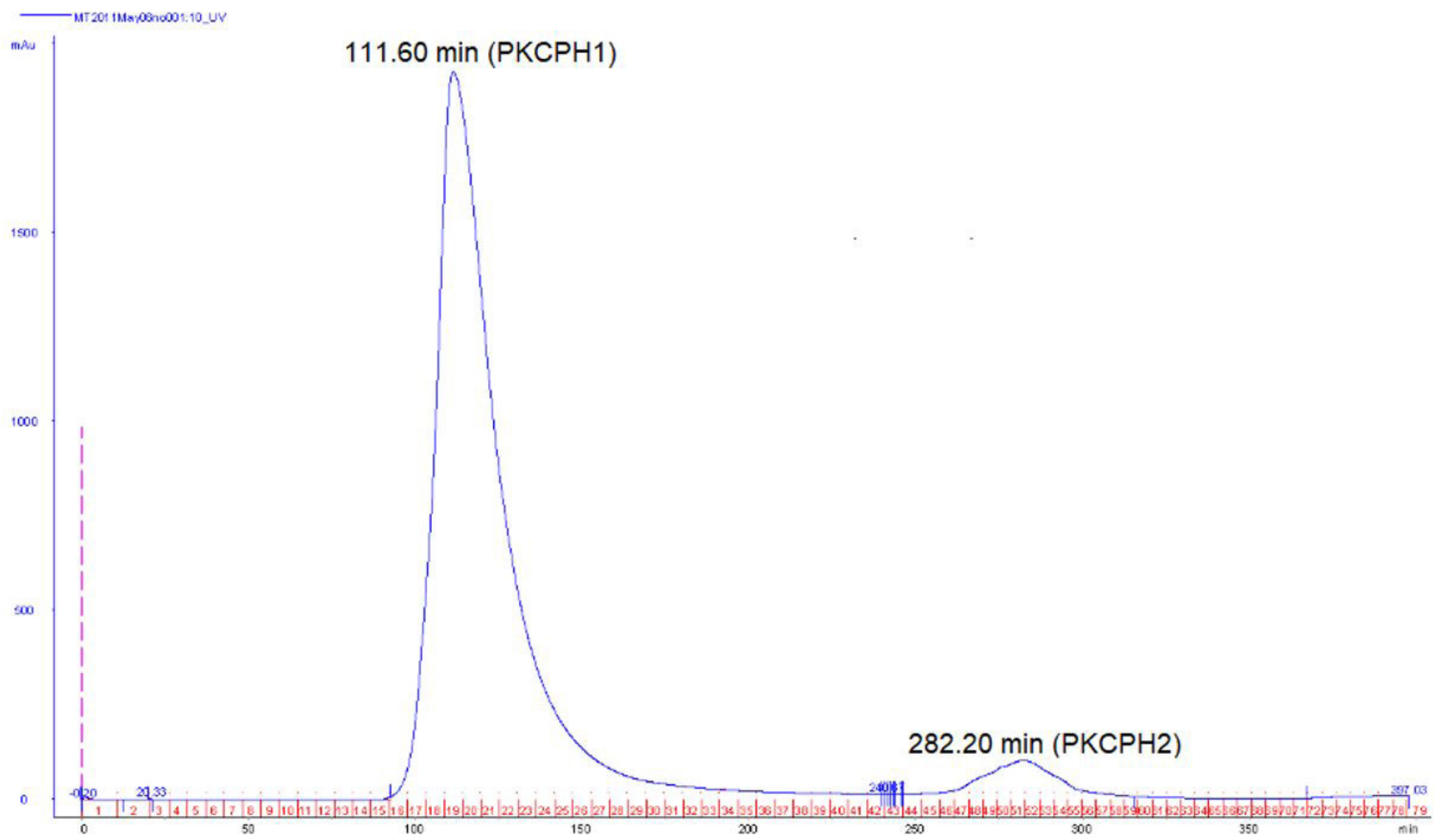

Figure 1. Size exclusion chromatogram of fractions PKCPH1 and PKCPH2.

electrophoresis, however, $\mathrm{PKCPH} 2$ was not initially visualized in PKCPH gel-like image (Figure 2B) due to its relatively low concentration. With a larger scale of chromatogram, a small single peak of PKCPH2 (Figure 2D) was observed. It has been reported that molecular size is one of the factors that affects functional properties of a peptide (Sarmadi \& Ismail, 2010). In general, bioactive peptide with molecular weight approximately $6 \mathrm{kDa}$ or less possesses diverse functional properties and high stability in the biological system (Chai et al., 2021). Results showed that PKCPH1 (Figure 2C) could be a potential health promoting hydrolysate with multiple functionalities. Subsequently, it leads to further investigation on its antioxidant and anti-ACE activities.

There were more than $80 \%$ of total amino acid content determined in PKCP and PKCPH, with approximately $36 \%$ of hydrophobic amino acids and $32-33 \%$ of antioxidant amino acids (Table 1). For the hydrolysate fractions, higher total amino acid content was expected in PKCPH1 (59\%), with higher levels of hydrophobic (23\%) and antioxidant (26\%) amino acids, compared to $\mathrm{PKCPH} 2$ (23\%). Despite variation of purity, PKCP, PKCPH and PKCPH1 shared a similar trend in terms of the quantity of different amnio acids, where glutamine was found the highest among all amino acids, followed by arginine, asparagine and leucine. Similarly, PKCPH2 had the highest amount of glutamine, followed by leucine and arginine. It has been reported that the potential biological functions of protein hydrolysate are related to the presence of cationic, hydrophobic and aromatic amino acids (Yu et al., 2012; Yang et al., 2017; Sun et al., 2019), such as lysine and arginine were shown to enhance antimicrobial activity of peptides (Seyedjavadi et al., 2019), and tyrosine was reported to contribute in vitro cellular antioxidant activities (Sun et al., 2019). The exposure of hydrophobic amino acids provides binding sites for free radicals in the environment to react with the peptide, thus reducing oxidizing stress in the biological system (Chai et al., 2021). For examples, Alcalase ${ }^{\circledR}$ hydrolysates of defatted walnut (Sheng et al., 2019) and soybean (Zhang et al., 2019), containing methionine, leucine, isoleucine, proline and valine, showed protection ability against cellular oxidative damage. The surface hydrophobicity index $\left(\mathrm{H}_{\mathrm{o}}\right)$ of the hydrolysate fractions or peptides could be an indicator of their bioactivities. In present study, PKCPH1 had the highest $\mathrm{H}_{\mathrm{o}}$ value $(79.60 \pm 0.01)$ and was significantly different $(p<0.05)$ compared to the PKCPH2 (11.97 \pm 0.01$)$. Results were in agreement with their amino acid profiles (Table 1), suggesting PKCPH1 had great potential of bioactivity. Furthermore, NMR spectroscopy was performed on PKCPH1 to ascertain the presence of specific functional groups. The chemical shift of NMR proton ${ }^{1} \mathrm{H}$ provides a general understanding of the structure of the peptide. Result (Figure 3 ) showed the presence of less shielded amides (7.04-6.75 ppm) within the aromatic region (6-8 ppm) and more shielded amines (1.50-2.00 ppm) within the amino group (1-5 ppm). Besides, the possibility of the presence of aliphatic groups, alkenes and heteroaromatic groups was taken into account. The presence of functional groups was further confirmed with the chemical shift of the isotope ${ }^{13} \mathrm{C}$, where amide $(170.0 \pm 3.0 \mathrm{ppm})$ and carbonyl groups, namely carboxyls (170.0-180.0 ppm), and ketones (205.0-215.0 ppm) 
(A)
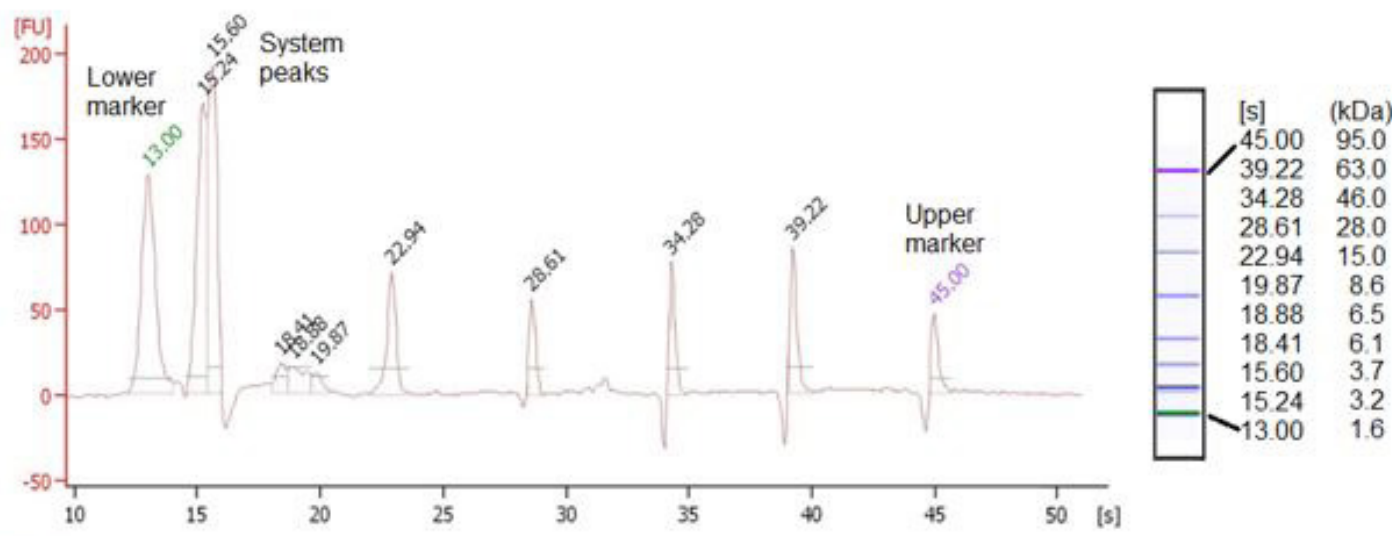

(B)
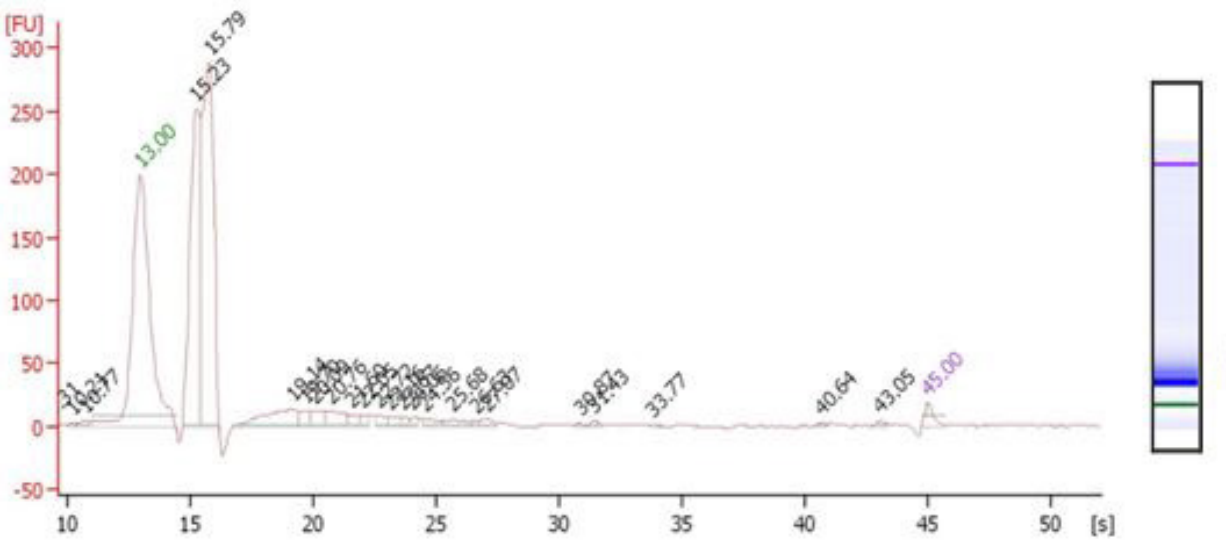

$\begin{array}{lc}{[\mathrm{s}]} & (\mathrm{kDa}) \\ 19.14 & 7.1\end{array}$

(C)
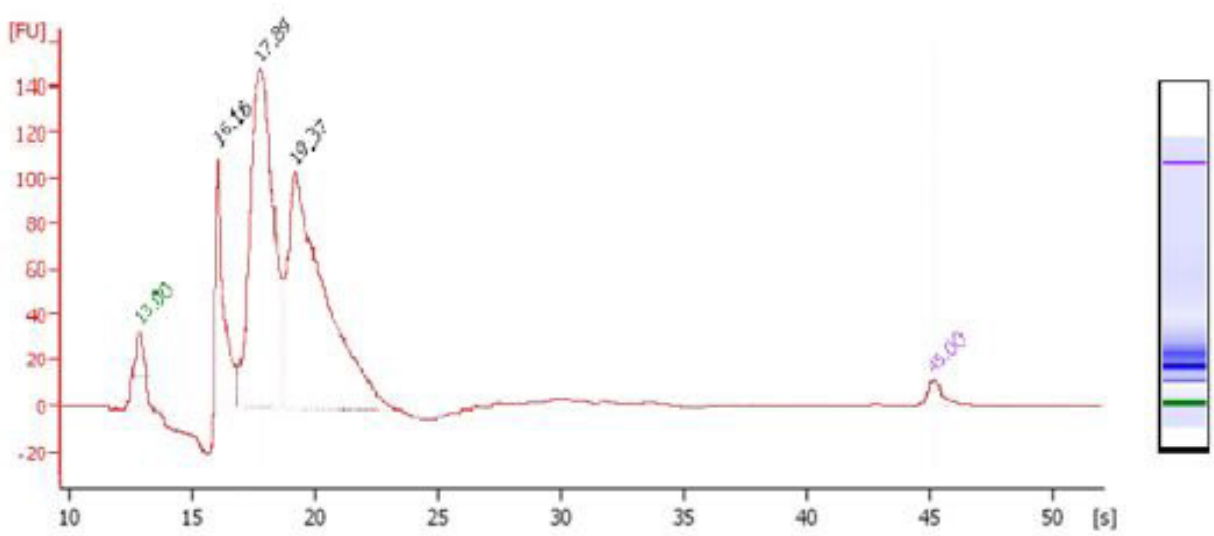

[s] (kDa)

$19.37 \quad 6.3$

$17.89 \quad 4.9$

(D)
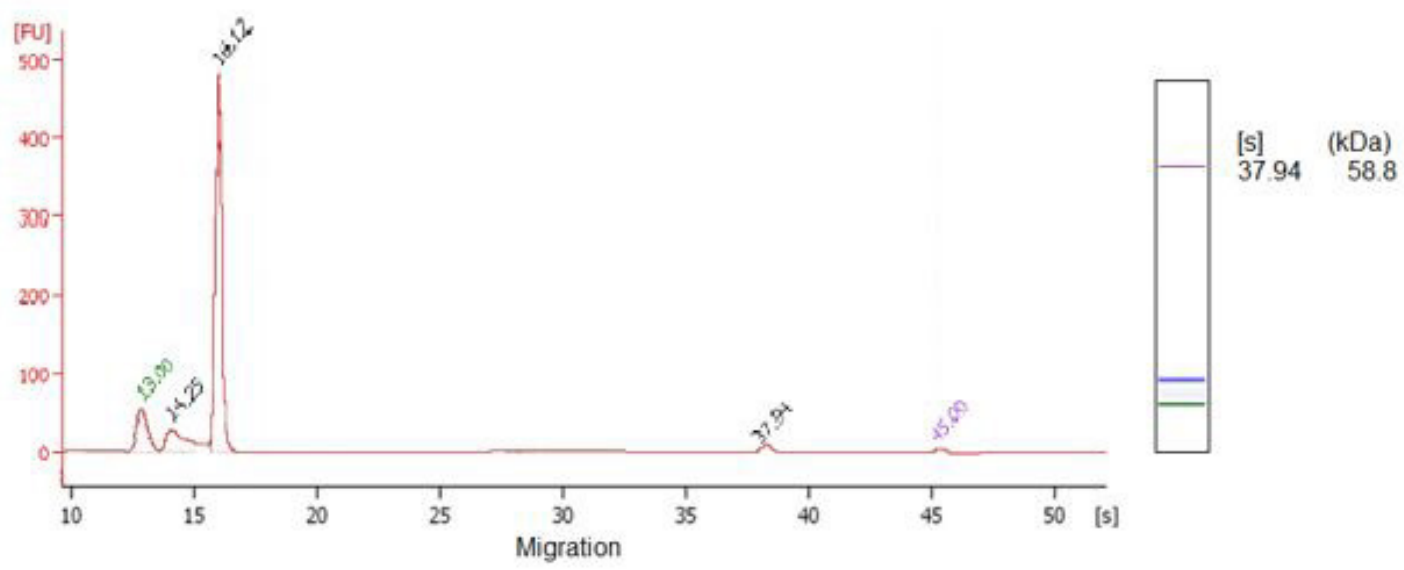

Figure 2. Electropherograms and gel-like images of (A) protein ladder; (B) palm kernel cake protein hydrolysate (PKCPH); (C) fraction 1 (PKCPH1); and (D) fraction 2 (PKCPH2). 
Table 1. Amino acid content (\%) in palm kernel cake protein (PKCP), hydrolysate (PKCPH) and fractions (PKCPH1 and PKCPH2).

\begin{tabular}{|c|c|c|c|c|}
\hline Amino acids & PKCP & PKCPH & PKCPH1 & $\mathrm{PKCPH} 2$ \\
\hline Ala & 4.37 & 4.16 & 2.70 & 1.68 \\
\hline Arg & 10.29 & 10.16 & 7.67 & 2.53 \\
\hline Asp $^{\mathrm{a}}$ & 8.35 & 8.02 & 6.42 & 1.90 \\
\hline $\mathrm{Glu}^{\mathrm{b}}$ & 14.86 & 14.16 & 12.96 & 2.94 \\
\hline Gly & 4.31 & 4.10 & 2.74 & 1.25 \\
\hline His & 2.28 & 2.07 & 1.42 & 0.61 \\
\hline Ile & 4.28 & 4.16 & 2.67 & 1.33 \\
\hline Leu & 7.07 & 6.92 & 4.71 & 2.58 \\
\hline Lys & 2.53 & 2.83 & 2.31 & 0.63 \\
\hline Met & 2.53 & 2.39 & 1.68 & 0.75 \\
\hline Phe & 4.72 & 4.55 & 3.01 & 2.06 \\
\hline Pro & 3.43 & 3.93 & 2.45 & 1.08 \\
\hline Ser & 3.52 & 3.46 & 2.48 & 1.11 \\
\hline Thr & 2.36 & 2.29 & 1.54 & 0.68 \\
\hline Tyr & 2.56 & 2.58 & 1.31 & 0.83 \\
\hline Val & 5.77 & 6.65 & 3.64 & 2.00 \\
\hline Total amino acid & 83.23 & 82.43 & 59.71 & 23.96 \\
\hline Hydrophobic amino acids ${ }^{c}$ & 36.48 & 36.86 & 23.60 & 12.73 \\
\hline Antioxidant amino acids ${ }^{\mathrm{d}}$ & 33.11 & 32.05 & 26.10 & 7.66 \\
\hline
\end{tabular}

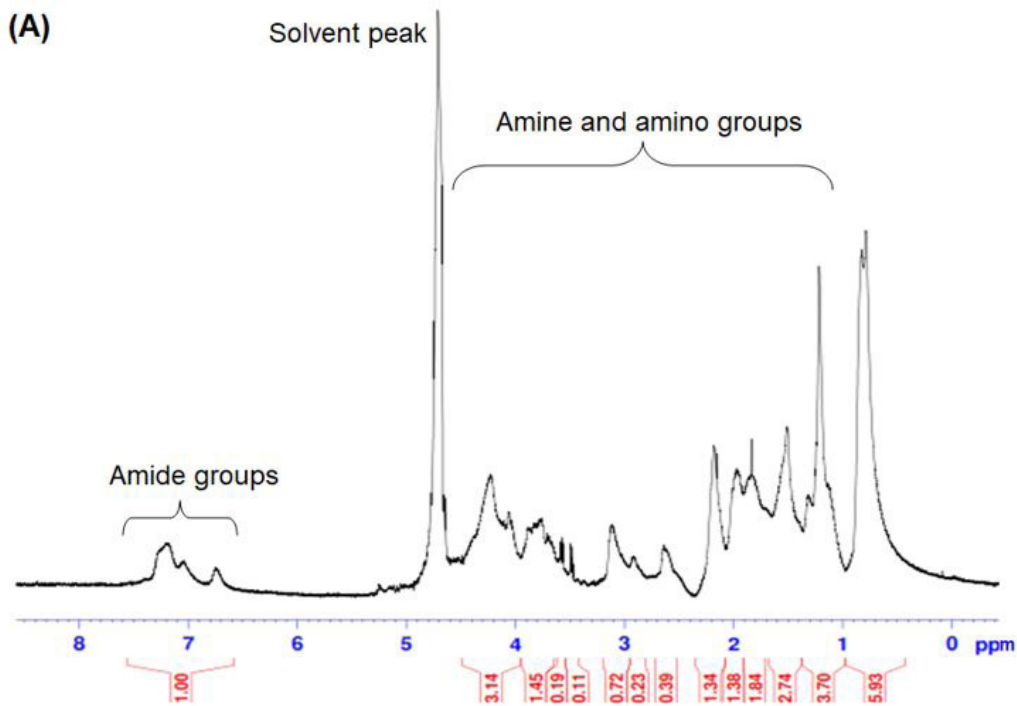

(B)

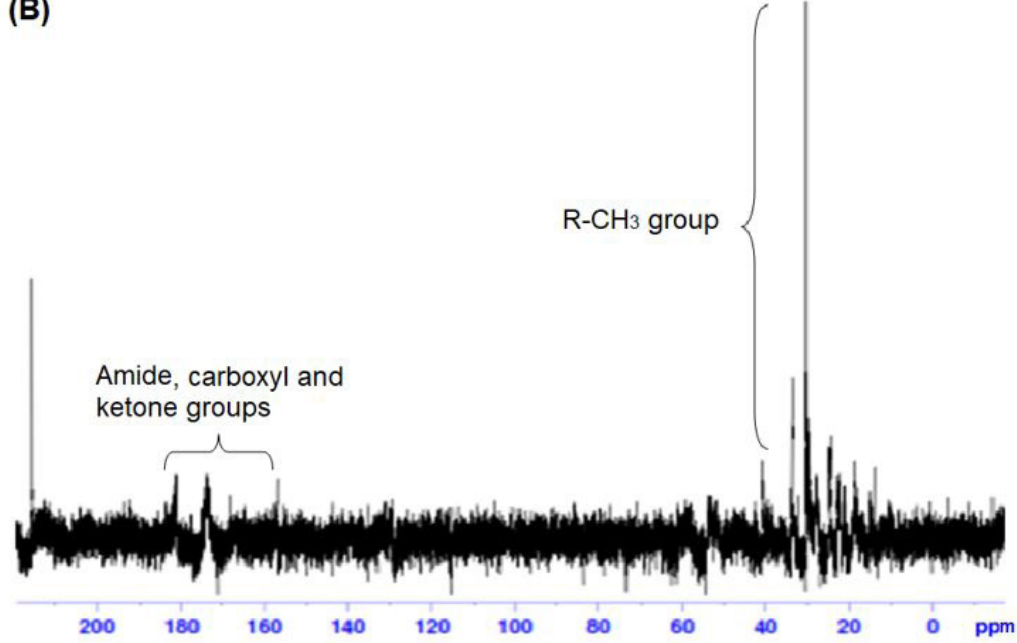

Figure 3. (A) ${ }^{1} \mathrm{H}$ and; (B) ${ }^{13} \mathrm{C}$ NMR spectra of PKCPH1. 
were determined. The stretching frequency of $1700-1500 \mathrm{~cm}^{-1}$ and $1580-1490 \mathrm{~cm}^{-1}$ suggested the presence of functional groups amide I and amide II $\mathrm{C}=\mathrm{O}$ and $\mathrm{C}-\mathrm{N}$.

\subsection{Antioxidant properties}

Table 2 shows that the antioxidant activity increased with greater purity of the samples, where the highest DPPH $\left(\mathrm{EC}_{50} 0.10 \mathrm{mg} / \mathrm{mL}\right)$ and superoxide anion $(46.32 \%)$ free radical scavenging activities, ORAC value [398.88 $\mu$ mol Trolox ${ }^{\circledR}$ equivalence $(\mathrm{TE}) / \mathrm{g}]$ and FRAP value $\left(166.43 \mu \mathrm{M} \mathrm{FeSO}{ }_{4}\right)$ were determined in $\mathrm{PKCPH1}$, although the ABTS free radical scavenging activity $(320 \mu \mathrm{mol} \mathrm{TE} / \mathrm{g})$ was lower than PKCP $(416 \mu \mathrm{mol} \mathrm{TE} / \mathrm{g})$ and the FIC activity (14.25\%) was similar to PKCPH (14.72\%). Interestingly, PKCPH2 exhibited the highest FIC activity $(21.30 \%)$ among all samples but its antioxidant activity was not detected in DPPH, ABTS, FRAP and ORAC assays. This could be due to differences in amino acid profile and structural properties compared to PKCPH1. Both DPPH and ABTS free radical scavenging assays are well-established methods for measuring the capacities of hydrogen or electron donors, including lipophilic and hydrophilic compounds, in neutralization of free radicals (Ma et al., 2010). Results indicated that $\mathrm{PKCPH1}$ was a potential free radical scavenger compared to some reported fruit samples, including pomegranate, olive, sweetsop and others (Fu et al., 2011). FRAP is a comparable method to DPPH and ABTS assays because it is also based on electron transfer mechanism, but to reduce a ferric salt $\left(\mathrm{Fe}^{3+}\right)$ to ferrous salt $\left(\mathrm{Fe}^{2+}\right)$ under acidic condition. Overall, samples exhibited dose-dependent reducing potential effectively in comparison to standard Trolox ${ }^{\circledR}$. Similar phenomenon was observed in a study of García-Nebot et al. (2014), where the presence of high amounts of Tyr, His, Met amino acid residues in lunasin was suggested to be responsible for antioxidant activities. Moreover, ORAC assay is commonly used to measure the relative potential of antioxidants in preventing biological molecules from free radical attacks. In this assay, samples were exposed to a peroxyl radical generator, $\mathrm{AAPH}$, and the oxidative degradation of fluorescein was measured. Results suggested that all samples had high antioxidant capacities compared with other plant sources, such as strawberry $(154 \mu \mathrm{mol} \mathrm{TE} / \mathrm{g})$, plum $(80 \mu \mathrm{mol} \mathrm{TE} / \mathrm{g})$, whole red grape $(36 \mu \mathrm{mol} \mathrm{TE} / \mathrm{g})$ and orange (52 $\mu \mathrm{mol} \mathrm{TE/g)} \mathrm{(Wang} \mathrm{et} \mathrm{al.,} \mathrm{1996).}$
Furthermore, PKCPH1 exhibited approximately 4 folds higher superoxide anion free radical scavenging activity than PKCP, although it was much lower compared to standard ascorbic acid $(73 \%)$. Comparable inhibition potency on superoxide free radicals was also observed in $\mathrm{PKCPH} 2$, but it was about $50 \%$ less than PKCPH1. Superoxide free radicals are commonly involved in promoting oxidative reactions. This is mainly due to their ability to reduce transition metals, thus releasing protein-bound metals and forming hydroperoxyl radicals which could initiate lipid oxidation (Elias et al. 2008). Transitional metals are believed to serve as catalysts to initiate the formation of radicals. Thus, chelating agents are important for stabilizing transitional metals in living system via inhibiting the generation of free radicals to delay or inhibit oxidative damage (Siddhuraju, 2006). Results showed that all samples generally exhibited weak chelating effects on ferric ions compared to standard EDTA (100\% inhibition). Some distinctive amino acid compositions, such as phosphoserine, glutamic acid, aspartic acid, histidine and cysteine (Tong et al., 2000), of antioxidative peptides have been reported to exert chelation on transitional metal ions, such as copper and iron (Kim et al., 2007), through the formation of intermolecular metal bridging (Sonklin et al., 2018). Nevertheless, lacking of histidine residue with imidazole ring in PKCP showed a great impact on its FIC activity.

Food proteins or peptides owe their antioxidative properties to the constituent amino acids as well as the conformational structure and hydrophobicity properties (Yu et al., 2012; Yang et al., 2017; Sun et al., 2019). The presence of aromatic amino acid residues in the peptide sequence, such as Tyr, His, Trp and Phe, contributes peroxidation inhibition by donating their protons to neutralize the free radicals (Rajapakse et al., 2005; Chen et al., 1998). Furthermore, peptides with high hydrophobic indexes usually show potent antioxidant properties. It was evidenced in the present study when $\mathrm{PKCPH}$ was partially fractionated into $\mathrm{PKCPH} 1$ and $\mathrm{PKCPH} 2$. Results indicated that PKCPH1 with a significantly $(p<0.05)$ high $\mathrm{H}_{\mathrm{o}}$ value exhibited high levels of antioxidant capacity compared to PKCPH2. A close relationship between the hydrophobicity nature and the free radical trapping ability of a peptide is developed during proteolysis, with the change of protein structure, thus resulting an upsurge of bioactivity (Sun et al., 2019; Chai et al., 2021). Future study on amino acid sequencing should be carried out to elucidate the possible structure of functional PKCPH1.

Table 2. Antioxidant and anti-ACE activities of palm kernel cake protein (PKCP), hydrolysate (PKCPH) and fractions (PKCPH1 and PKCPH2).

\begin{tabular}{|c|c|c|c|c|c|c|c|}
\hline Sample* & $\begin{array}{c}\mathrm{DPPH} \\
(\mu \mathrm{mol} \mathrm{TE} / \mathrm{g}) \\
{\left[\mathrm{EC}_{50} \mathrm{mg} / \mathrm{mL}\right]}\end{array}$ & $\begin{array}{c}\text { ABTS } \\
(\mu \mathrm{mol} \mathrm{TE} / \mathrm{g})\end{array}$ & $\begin{array}{c}\text { FRAP } \\
\left(\mu \mathrm{M} \mathrm{FeSO}_{4}\right)\end{array}$ & $\begin{array}{c}\text { ORAC } \\
(\mu \mathrm{mol} \mathrm{TE} / \mathrm{g})\end{array}$ & $\begin{array}{c}\text { SAFRC } \\
\text { (Inhibition \%) }\end{array}$ & $\begin{array}{c}\text { FIC } \\
\text { (Inhibition \%) }\end{array}$ & $\begin{array}{c}\text { ACE inhibition } \\
(\%)\end{array}$ \\
\hline PKCP & $\begin{array}{c}112.90 \pm 0.06^{\mathrm{a}} \\
{[0.16]}\end{array}$ & $416.00 \pm 5.77^{a}$ & $121.98 \pm 7.38^{\mathrm{a}}$ & $265.83 \pm 1.87^{a}$ & $12.15 \pm 0.96^{\mathrm{a}}$ & $10.23 \pm 0.02^{\mathrm{a}}$ & $69.65 \pm 1.50^{\mathrm{a}}$ \\
\hline PKCPH & $\begin{array}{c}199.17 \pm 0.72^{\mathrm{b}} \\
{[0.12]}\end{array}$ & $253.33 \pm 0.01^{\mathrm{b}}$ & $135.00 \pm 3.78^{\mathrm{b}}$ & $247.89 \pm 0.01^{\mathrm{b}}$ & $13.89 \pm 0.01^{\mathrm{b}}$ & $14.72 \pm 0.01^{\mathrm{b}}$ & NA \\
\hline PKCPH1 & $\begin{array}{c}\mathrm{NA} \\
{[0.10]}\end{array}$ & $320.00 \pm 0.01^{\mathrm{c}}$ & $166.43 \pm 9.37^{c}$ & $389.88 \pm 0.01^{\mathrm{c}}$ & $46.32 \pm 0.01^{c}$ & $14.25 \pm 0.01^{\mathrm{b}}$ & $54.54 \pm 2.30^{\mathrm{b}}$ \\
\hline РКСРН2 & ND & $\mathrm{ND}$ & ND & ND & $28.95 \pm 0.01^{\mathrm{d}}$ & $21.30 \pm 0.01^{\mathrm{c}}$ & $77.29 \pm 0.90^{c}$ \\
\hline
\end{tabular}

${ }^{\star}$ Data are means of three determinations with standard deviations. ${ }^{\mathrm{a}-\mathrm{d}}$ Data in each column which are annotated with different superscripts are significantly different $(p<0.05)$; ND, not detected; NA, not analyzed. 


\subsection{ACE inhibitory activity}

Table 2 shows that PKCPH2 exhibited the highest anti-ACE activity among the tested samples, and higher than the standard captopril (60.5\%) at $1.5 \mathrm{ng} / \mathrm{mL}$ using the same assay. Despite of weak antioxidant activity, its potential anti-ACE activity shows that PKCPH could impart multifunctional health benefits. A study of Zhang et al. (2020) suggested that a peptide with both antioxidant and anti-ACE properties might possess effective therapeutic effect on some complicated diseases. Similar studies on peptides and protein hydrolysates, such as those from Amaranth seed (Fritz et al. 2011) and red lentil (Boye et al. 2010), reported significant anti-ACE activities. It has been demonstrated that short peptides with C-terminal Arg, Lys or Pro residues contribute most strongly to anti-ACE activity (Erdmann et al. 2008). Although the presence of Arg, Lys and Pro in PKCPH2 could possibly contribute to the anti-ACE activity, its large molecular size certainly did not agree with the aforementioned studies. However, its anti-ACE activity could be relevant to the conformation alteration of protein after proteolysis (Sarmadi \& Ismail 2010; Chai et al., 2021), for example, the arising of anti-ACE activity was reported in Amaranth seed protein hydrolysate using enzyme Alcalase ${ }^{\circledR}$ (Fritz et al. 2011). Targeting on the $\mathrm{C}$ domain of ACE inhibitor, a molecular docking study on selected ACE inhibitors reported that Ile in LIVT peptide $\left(\mathrm{IC}_{50} 0.11 \mu \mathrm{M}\right)$ increased the binding affinity to ACE. Additionally, its vigorous backbone movement in Asp300-Val350 explained the significant anti-ACE activity (Fang et al., 2019). Although complete mechanism of the ACE inhibitor is yet to be elucidated, the structure-function relationship between $\mathrm{PKCPH} 2$ and $\mathrm{ACE}$ could be examined through molecular docking in the future.

\subsection{Cytotoxicity assessments}

Protein isolation or extraction involves the use of acid, alkaline and/or salt solutions. Using strong alkaline in protein isolation could severely alter the natural protein structure and might induce the formation of toxic residues (GDe Groot \& Slump, 1969; Ng \& Mohd Khan, 2012). Besides in vitro antioxidant and anti-ACE analyses, the possible cellular and genetic cytotoxicity of the newly found peptides should be evaluated before proceeding with animal toxicity study. MTT assay is a well-established cell viability test to indicate the cytotoxicity level of interested compounds. High cell viability (87-92\%) or survival percentage results (Table 3 ) implied that the metabolic activity of L-929 cells was sustained despite the incubation with high concentrations of samples. It has been reported that the metabolic performance of an intact cell is directly related to its mitochondrial dehydrogenase activity. Failure of mitochondrial function happens commonly due to the accumulation of oxidative substances that induce oxidative stress and it is followed by cell apoptosis (Guo et al., 2013). Therefore, the role of antioxidants in achieving homeostasis through maintaining redox balance is recognized. Cell viability can be further verified with additional parameters in the future study, such as determination of NADH cytochrome $\mathrm{c}$ reductase activities.

The effects of $\mathrm{PKCPH}$ and $\mathrm{PKCPH} 1$ on the integrity of DNA molecules were evaluated using alkaline comet assay. According to Hartmann et al. (2003), this assay is a powerful tool for mechanistic genotoxicity testing on new pharmaceutical drugs. It has also been well established for detecting broken strand of the DNA in a single cell (Collins, 2004). The selection of sample concentration for comet assay is generally based on its solubility and/or the determination of growth inhibition or viability of the tested cells directly after treatment (Hartmann et al., 2003). As verified in the MTT assay, PKCPH and PKCPH1 did not show cytotoxic effect at all concentrations. Thus, the highest concentrations, $2 \mathrm{mg} / \mathrm{mL}$ and $1 \mathrm{mg} / \mathrm{mL}$, respectively, of both samples were applied in the comet assay. Results (Table 3) showed that negligible cytotoxicity and gene/DNA damage on V79-4 cells were observed after treatment with samples for $24 \mathrm{~h}$. For positive control, $\mathrm{H}_{2} \mathrm{O}_{2}$-treated cells showed a severe DNA damage with tail moment of 15.43 and appeared as a leak in the gel image (result not shown). Notably, oxidative stress imparts significant health issues especially the unforeseen genetic mutation that carries the risk of cancer development. For example, prolong exposure of skin tissues to UV radiation will increase the production of reactive oxygen species and the dissolution of DNA strands, thus causing onset of cell death or development of cancerous cells (Han et al., 2004).

In a series of experiments preceding the mutagenicity studies, it was ascertained that the highest dosages of $\mathrm{PKCPH}$ would not influence the viability of AMES indicator bacteria. Results (Table 3) showed that sample was neither mutagenic nor toxic towards $S$. Typhimurium strains TA98 and TA100. With different dosages of sample, the mutation frequencies did not change significantly compared to spontaneous mutation frequencies suggesting $\mathrm{PKCPH}$ did not induce a significant

Table 3. Cell viability and cytotoxicity evaluations of palm kernel cake protein hydrolysate (PKCPH) and fraction 1 (PKCPH1).

\begin{tabular}{|c|c|c|c|c|c|c|c|}
\hline \multirow{3}{*}{$\begin{array}{c}\text { Assay }^{*} \\
\text { Cell line } \\
\text { Analysis }\end{array}$} & \multirow{3}{*}{$\begin{array}{c}\text { MTT } \\
\text { L-929 } \\
\text { Viability (\%) }\end{array}$} & \multirow{2}{*}{\multicolumn{2}{|c|}{$\begin{array}{l}\text { Comet } \\
\text { V79-4 } \\
\end{array}$}} & \multicolumn{2}{|c|}{ AMES $^{\#}$} & \multirow{2}{*}{\multicolumn{2}{|c|}{$\begin{array}{c}\mathrm{MNi}^{\#} \\
\mathrm{~V} 79-4 \\
\end{array}$}} \\
\hline & & & & \multirow{2}{*}{$\begin{array}{c}\text { TA98 } \\
-S 9(+S 9) \\
\end{array}$} & \multirow{2}{*}{$\frac{\text { TA100 }}{-S 9(+S 9)}$} & & \\
\hline & & Tail moment & Remark & & & $\begin{array}{c}\text { Count } \\
\text { (Frequency, \%) }\end{array}$ & Remark \\
\hline PКСРН ( $2 \mathrm{mg} /$ plate or $2 \mathrm{mg} / \mathrm{mL}$ ) & $92.57 \pm 0.08^{\mathrm{a}}$ & $1.75 \pm 0.26^{\mathrm{a}}$ & Negligible & $\begin{array}{c}10 \pm 2.1^{\mathrm{a}} \\
\left(23 \pm 8.7^{\mathrm{b}}\right)\end{array}$ & $\begin{array}{c}11 \pm 4.0^{\mathrm{a}} \\
\left(32 \pm 10.8^{\mathrm{b}}\right)\end{array}$ & $\begin{array}{c}10 \pm 3^{\mathrm{a}} \\
\left(2.0^{\mathrm{b}}\right)\end{array}$ & Negligible \\
\hline PКCPH1 (1 mg/mL) & $87.81 \pm 0.01^{\mathrm{b}}$ & $0.54 \pm 0.06^{\mathrm{b}}$ & Negligible & $\begin{array}{l}\mathrm{NA} \\
(\mathrm{NA})\end{array}$ & $\begin{array}{l}\text { NA } \\
\text { (NA) }\end{array}$ & $\begin{array}{l}\mathrm{NA} \\
(\mathrm{NA})\end{array}$ & $\begin{array}{l}\mathrm{NA} \\
(\mathrm{NA})\end{array}$ \\
\hline Negative control $^{\dagger}$ & 100 & $1.18 \pm 0.26^{c}$ & Negligible & $\begin{array}{c}10 \pm 3.5^{\mathrm{a}} \\
\left(28 \pm 7.9^{\mathrm{c}}\right)\end{array}$ & $\begin{array}{c}13 \pm 0.6^{\mathrm{a}} \\
\left(44 \pm 4.9^{\mathrm{c}}\right)\end{array}$ & $\begin{array}{l}5 \pm 3^{\mathrm{c}} \\
\left(1.0^{\mathrm{d}}\right)\end{array}$ & Negligible \\
\hline
\end{tabular}

${ }^{*}$ Data are means of three determinations with standard deviations. ${ }^{*}$ Revertant colony counts. ${ }^{*}$ Refers to respective method. ${ }^{\text {a-c }}$ Data in each column which are annotated with different superscripts are significantly different $(p<0.05)$; NA, not analyzed; + S9, presence of S9; -S9, absence of S9; S9, metabolic activation extract. 
Table 4. Body weight and absolute organ weight of albino rats in acute oral toxicity test.

\begin{tabular}{|c|c|c|}
\hline \multicolumn{3}{|c|}{ Body weight $(\mathrm{g})$} \\
\hline Week & Control group $(\mathrm{n}=5)^{*}$ & Treated group $(\mathrm{n}=10)^{*}$ \\
\hline 0 & $243.48 \pm 46.66^{\mathrm{a}}$ & $219.06 \pm 31.79^{\mathrm{a}}$ \\
\hline 1 & $279.28 \pm 62.32^{\mathrm{a}}$ & $241.34 \pm 31.62^{\mathrm{a}}$ \\
\hline 2 & $301.60 \pm 81.30^{\mathrm{a}}$ & $242.80 \pm 28.05^{\mathrm{b}}$ \\
\hline \multicolumn{3}{|c|}{ Absolute organ weight (g) (\% per body weight) } \\
\hline Organ & Control group $(\mathbf{n}=5)^{\star}$ & Treated group $(\mathbf{n}=10)^{\star}$ \\
\hline Brain & $1.76 \pm 0.11^{\mathrm{a}}\left(0.62 \pm 0.19^{\mathrm{a}}\right)$ & $1.68 \pm 0.07^{\mathrm{a}}\left(0.62 \pm 0.10^{\mathrm{a}}\right)$ \\
\hline Spleen & $0.60 \pm 0.23^{\mathrm{a}}\left(0.20 \pm 0.04^{\mathrm{a}}\right)$ & $0.44 \pm 0.07^{\mathrm{b}}\left(0.16 \pm 0.03^{\mathrm{b}}\right)$ \\
\hline Liver & $12.42 \pm 4.18^{\mathrm{a}}\left(4.06 \pm 0.35^{\mathrm{a}}\right)$ & $11.12 \pm 2.22^{\mathrm{a}}\left(3.99 \pm 0.42^{\mathrm{a}}\right)$ \\
\hline Heart & $0.98 \pm 0.17^{\mathrm{a}}\left(0.33 \pm 0.04^{\mathrm{a}}\right)$ & $0.88 \pm 0.09^{\mathrm{a}}\left(0.32 \pm 0.04^{\mathrm{a}}\right)$ \\
\hline Pancreas & $0.72 \pm 0.20^{\mathrm{a}}\left(0.24 \pm 0.07^{\mathrm{a}}\right)$ & $0.79 \pm 0.13^{\mathrm{a}}\left(0.29 \pm 0.06^{\mathrm{a}}\right)$ \\
\hline Lung & $1.78 \pm 0.47^{\mathrm{a}}\left(0.59 \pm 0.03^{\mathrm{a}}\right)$ & $1.82 \pm 0.23^{\mathrm{a}}\left(0.67 \pm 0.10^{\mathrm{b}}\right)$ \\
\hline Kidney & $2.36 \pm 0.47^{\mathrm{a}}\left(0.80 \pm 0.07^{\mathrm{a}}\right)$ & $1.88 \pm 0.31^{\mathrm{b}}\left(0.69 \pm 0.11^{\mathrm{b}}\right)$ \\
\hline Stomach & $1.87 \pm 0.48^{\mathrm{a}}\left(0.62 \pm 0.07^{\mathrm{a}}\right)$ & $1.78 \pm 0.33^{\mathrm{a}}\left(0.65 \pm 0.12^{\mathrm{a}}\right)$ \\
\hline
\end{tabular}

increase of the number of revertant colonies in the presence and absence of S9 metabolite. In contrast, at least two folds or more revertant colonies per plate were observed in the treatment with mutagenic substances, such as sodium azide (1291 counts), 4-nitro-o-phenylenediamine (41 counts) and 2-aminoanthracene (663 counts), compared to the negative control. Similar study reported that both strains of $S$. Typhimurium are also responsive to aflatoxin B1 (AFB1) and Benzo(a)pyrene (BaP) showing cytotoxicity effects (Ben Sghaier et al., 2011). Furthermore, $\mathrm{MNi}$ assay was performed on cell line V79-4 with PKCPH to detect the possible aberrations of chromosome. The number of $\mathrm{MNi}$ in at least 1500 mononucleated cells was scored and the frequency of MNi should be less than one-third of the main nucleus. Results (Table 3) showed that PKCPH did not induce a significant increase of the number of $\mathrm{MNi}$ compared to the positive control, mitomycin, which significantly induced the formation of $\mathrm{MNi}$ with 82 counts or $16.4 \%$ higher frequency than the normal cells. A MNi comprises a portion of chromatin surrounded by a separate nuclear membrane, which arises either by condensation of acentric chromosomes that remain separated at anaphase due to their inability to attach to the spindle during cell division, or by exclusion of intact centric chromosomes from anaphase segregation (Mitchell \& Combes, 1997). Therefore, the presence of $\mathrm{MNi}$ suggests the disruption of small amount of decondensed chromatins. The increasing number of $\mathrm{MNi}$ is an evidence of the induction of damage on chromosome structure or the change in chromosome number (Rodeiro et al., 2006). Collectively, the results of in vitro cytotoxic analyses using different cell lines demonstrated the safe characteristics of PKCPH and $\mathrm{PKCPH} 1$, and also provided an impetus for future application as antioxidants in human diet.

In vivo acute oral toxicity assay provides preliminary information on the potential health risks through a short-term oral ingestion. According to our observation and collected data (Table 4), there was no incidence of death and no remarkable loss of body weight in both $\mathrm{PKCPH}$-treated and control groups.
Through daily examination on the experimental animals, $\mathrm{PKCPH}$ did not induce noticeable signs of illnesses, such as diarrhea, hair loss, changes of skin, eyes, respiratory system, mucous membrane and motor activity, as well as symptoms of tremor, ataxia-inability or walking backwards. All animals appeared normal and healthy throughout the study indicating $\mathrm{PKCPH} \mathrm{as}$ a non-toxic product. Going forward, the recovery potential and mechanism studies of PKCPH on oxidative stressed (Yu et al., 2012; Yin et al., 2014) or disease infected (Adebayo et al., 2017; $\mathrm{He}$ et al., 2019) animal models will be another interesting research direction.

\section{Conclusions}

Collectively, $\mathrm{PKCP}$ and $\mathrm{PKCPH}$, including fractions $\mathrm{PKCPH} 1$ and $\mathrm{PKCPH}$, were characterized and their potential antioxidant and anti-ACE activities were analyzed. The amino acid composition profiles suggested possible contribution of hydrophobic amino acids in peptide to antioxidant activity. The mitigation of oxidative stress on cellular and animal models by using these bioactive peptides could be explored in future study. However, these partially purified peptides or hydrolysates may consist of impurities that could either hinder or promote in vivo bioactivity. Future attempts on purification, amino acid sequencing and chemical synthesis are required to further elucidate molecular characteristics before in vivo study. Furthermore, negligible toxicity outcomes from in-vitro cytotoxicity and in-vivo acute oral toxicity tests suggested that $\mathrm{PKCPH}$ is safe for consumption and can be applied as a potential functional ingredient. Future study on the effects of processing parameters and the stability of peptide could be taken into account. Besides, dietary intake of functional peptide could be an important approach to reveal the bioavailability and biotransformation after gastrointestinal digestion and absorption through brush border membrane. To further verify the potential bioactivity, additional studies are mandatory on the mechanisms and structure-activity relationships under physiological conditions.

\section{Conflicts of interest}

The authors declare no conflict of interest.

\section{Acknowledgements}

This study was financially supported by Science Fund (0501-02-SF1006) of the Ministry of Agriculture and Agro-Based Industry Malaysia. Authors acknowledge FGV Kernel Products Sdn. Bhd., Malaysia, for providing palm kernel cake; and Makmal Bioserasi ${ }^{\mathrm{TM}} \mathrm{UKM}$ for assisting the animal study.

\section{References}

Adebayo, J. O., Adewole, K. E., \& Krettli, A. U. (2017). Cysteine-stabilised peptide extract of Morinda lucida (Benth) leaf exhibits antimalarial activity and augments antioxidant defense system in $P$. bergheiinfected mice. Journal of Ethnopharmacology, 207, 118-128. http:// dx.doi.org/10.1016/j.jep.2017.06.026. PMid:28645782.

Aider, M., \& Barbana, C. (2011). Canola proteins: composition, extraction, functional properties, bioactivity, applications as a food ingredient and allergenicity - A practical and critical review. 
Trends in Food Science \& Technology, 22(1), 21-39. http://dx.doi. org/10.1016/j.tifs.2010.11.002.

Alimon, A. R. (2006). The nutritive value of palm kernel cake for animal feed. Palm Oil Development, 40, 12-14.

Alizadeh-Pasdar, N., \& Li-Chan, E. C. (2000). Comparison of protein surface hydrophobicity measured at various $\mathrm{pH}$ values using three different fluorescent probes. Journal of Agricultural and Food Chemistry, 48(2), 328-334. http://dx.doi.org/10.1021/jf990393p. PMid:10691636.

Ben Sghaier, M., Boubaker, J., Skandrani, I., Bouhlel, I., Limem, I., Ghedira, K., \& Chekir-Ghedira, L. (2011). Antimutagenic, antigenotoxic and antioxidant activities of phenolic-enriched extracts from Teucrium ramosissimum: Combination with their phytochemical composition. Environmental Toxicology and Pharmacology, 31(1), 220-232. http:// dx.doi.org/10.1016/j.etap.2010.11.001. PMid:21787689.

Boye, J. I., Roufik, S., Pesta, N., \& Barbana, C. (2010). Angiotensin I-coverting enzyme inhibitory properties and SDS-PAGE of red lentil protein hyrolysates. Lebensmittel-Wissenschaft + Technologie, 43(6), 987-991. http://dx.doi.org/10.1016/j.lwt.2010.01.014.

Chai, T.-T., Ee, K.-Y., Kumar, D. T., Manan, F. A., \& Wong, F.-C. (2021). Plant bioactive peptides: current status and prospects towards use on human health. Protein and Peptide Letters, 28(6), 623-642. http:// dx.doi.org/10.2174/0929866527999201211195936. PMid:33319654.

Chen, H. M., Muramoto, K., Yamauchi, F., Fujimoto, K., \& Nokihara, A. (1998). Antioxidative properties of histidine-containing peptides designed from peptide fragments found in the digests of a soybean protein. Journal of Agricultural and Food Chemistry, 46(1), 49-53. http://dx.doi.org/10.1021/jf970649w. PMid:10554195.

Chen, J., Liu, S., Ye, R., Cai, G., Ji, B., \& Wu, Y. (2013). Angiotensin-I converting enzyme (ACE) inhibitory tripeptides from rice protein hydrolysate: purification and characterization. Journal of Functional Foods, 5(4), 1684-1692. http://dx.doi.org/10.1016/j.jff.2013.07.013.

Collins, A. R. (2004). The comet assay for DNA damage and repair: principles, applications, and limitations. Molecular Biotechnology, 26(3), 249-261. http://dx.doi.org/10.1385/MB:26:3:249. PMid:15004294.

Cushman, D. W., \& Cheung, H. S. (1971). Spectrophotometric assay and properties of the angiotensin-converting enzyme of rabbit lung. Biochemical Pharmacology, 20(7), 1637-1648. http://dx.doi. org/10.1016/0006-2952(71)90292-9. PMid:4355305.

Ee, K. Y., Agboola, S., Rehman, A., \& Zhao, J. (2012). In vitro antioxidant and bioactive properties of raw and roasted wattle (Acacia victoriae Bentham) seed extracts. International Journal of Food Science \& Technology, 47(9), 2000-2008. http://dx.doi.org/10.1111/j.13652621.2012.03063.x.

Ee, K.-Y., Khoo, L.-Y., Ng, W.-J., Wong, F.-C., \& Chai, T.-T. (2019). Effects of bromelain and trypsin hydrolysis on the phytochemical content, antioxidant activity, and antibacterial activity of roasted butterfly pea seeds. Processes (Basel, Switzerland), 7(8), 534. http:// dx.doi.org/10.3390/pr7080534.

Elias, R. J., Kellerby, S. S., \& Decker, E. A. (2008). Antioxidant activity of proteins and peptides. Critical Reviews in Food Science and Nutrition, 48(5), 430-441. http://dx.doi.org/10.1080/10408390701425615. PMid:18464032.

Erdmann, K., Cheung, B. W. Y., \& Schroder, H. (2008). The possible roles of food derived bioactive peptides in reducing the risk of cardiovascular disease. The Journal of Nutritional Biochemistry, 19(10), 643-654. http://dx.doi.org/10.1016/j.jnutbio.2007.11.010. PMid:18495464.

Fang, L., Geng, M., Liu, C., Wang, J., Min, W., \& Liu, J. (2019). Structural and molecular basis of angiotensin-converting enzyme by computational modeling: Insights into the mechanisms of different inhibitors. PLoS One, 14(4), e0215609. http://dx.doi.org/10.1371/ journal.pone.0215609. PMid:30998765.

Feng, L., Peng, F., Wang, X., Li, M., Lei, H., \& Xu, H. (2019). Identification and characterization of antioxidative peptides derived from simulated in vitro gastrointestinal digestion of walnut meal proteins. Food Research International, 116, 518-526. http://dx.doi.org/10.1016/j. foodres.2018.08.068. PMid:30716976.

Fritz, M., Vecchi, B., Rinaldi, G., \& Añón, M. C. (2011). Amaranth seed protein hydrolysates have in vivo and in vitro antihypertensive activity. Food Chemistry, 126(3), 878-884. http://dx.doi.org/10.1016/j. foodchem.2010.11.065.

Fu, L., Xu, B. T., Xu, X. R., Gan, R. Y., Zhang, Y., Xia, E. Q., \& Li, H. B. (2011). Antioxidant capacities and total phenolic contents of 62 fruits. Food Chemistry, 129(2), 345-350. http://dx.doi.org/10.1016/j. foodchem.2011.04.079. PMid:30634236.

Galdón, B. R., Mesa, D. R., Rodríguez, E. M., \& Romero, C. D. (2010). Amino acid content in traditional potato cultivars from the Canary Islands. Journal of Food Composition and Analysis, 23(2), 148-153. http://dx.doi.org/10.1016/j.jfca.2009.08.009.

García-Nebot, M. J., Recio, I., \& Hernández-Ledesma, B. (2014). Antioxidant activity and protective effects of peptide lunasin against oxidative stress in intestinal Caco- 2 cells. Food and Chemical Toxicology, 65, 155-161. http://dx.doi.org/10.1016/j.fct.2013.12.021. PMid:24365261.

GDe Groot, A. P., \& Slump, P. (1969). Effects of severe alkaline treatment of proteins on amino acid composition and nutritive value. The Journal of Nutrition, 98(1), 45-56. http://dx.doi.org/10.1093/ jn/98.1.45. PMid:5814706.

Gibbs, B. F., Zougman, A., Masse, R., \& Mulligan, C. (2004). Production and characterization of bioactive peptides from soy hydrolysate and soy fermented food. Food Research International, 37(2), 123-131. http://dx.doi.org/10.1016/j.foodres.2003.09.010.

Guo, C., Sun, L., Chen, X., \& Zhang, D. (2013). Oxidative stress, mitochondrial damage and neurodegenerative diseases. Neural Regeneration Research, 8(21), 2003-2014. PMid:25206509.

Halim, R. M., Ramli, R., Che Mat, C. M., Hadi, N. A., Abu Bakar, N., \& Aziz, A. A. (2017). Highly digestible palm kernel cake (PKC) for animal feed. Malaysian Palm Oil Board, 758, 1-4. Retrieved from http://palmoilis.mpob.gov.my/publications/TOT/tot2017/ TT619-Rohaya.pdf

Han, J., Hankinson, S., Colditz, G. A., \& Hunter, D. J. (2004). Genetic variation in XRCC1, sun exposure, and risk of skin cancer. British Journal of Cancer, 91(8), 1604-1609. http://dx.doi.org/10.1038/ sj.bjc.6602174. PMid:15381933.

Hartmann, A., Plappert, U., Poetter, F., \& Suter, W.. (2003). Comparative study with the alkaline comet assay and the chromosome aberration test. Mutation Research, 536(1-2), 27-38. http://dx.doi.org/10.1016/ S1383-5718(03)00035-4. PMid:12694743.

He, R., Wang, Y., Yang, Y., Wang, Z., Ju, X., \& Yuan, J. (2019). Rapeseed protein-derived ACE inhibitory peptides LY, RALP and GHS show antioxidant and anti-inflammatory effects on spontaneously hypertensive rats. Journal of Functional Foods, 55, 211-219. http:// dx.doi.org/10.1016/j.jff.2019.02.031.

Ishak, F. A., Jamil, M. H., Abd Razak, A. S., Zamani, N. H. A., \& Ab Hamid, M. R. (2019). Development of animal feed from waste to wealth using napier grass and palm acid oil (PAO) from palm oil mill effluent (POME). Materials Today: Proceedings, 19(4), 1618-1627.

Jiang, Y., Zhao, D., Sun, J., Luo, X., Li, H., Sun, X., \& Zheng, F. (2019). Analysis of antioxidant effect of two tripeptides isolated from 
fermented grains (Jiupei) and the antioxidative interaction with 4-methylguaiacol, 4-ethylguaiacol, and vanillin. Food Science \& Nutrition, 7(7), 2391-2403. http://dx.doi.org/10.1002/fsn3.1100. PMid:31367368.

Kaniapan, S., Hassan, S., Ya, H., Patma Nesan, K., \& Azeem, M. (2021). The utilisation of palm oil and oil palm residues and the related challenges as a sustainable alternative in biofuel, bioenergy, and transportation sector: A review. Sustainability, 13(6), 3110. http:// dx.doi.org/10.3390/su13063110.

Kim, G. N., Jang, H. D., \& Kim, C. I. (2007). Antioxidant capacity of caseinphosphopeptides prepared from sodium caseinate using Alcalase. Food Chemistry, 104(4), 1359-1365. http://dx.doi.org/10.1016/j. foodchem.2007.01.065

Kum, W. H., \& Zahari, M. W. (2011). Utilisation of oil palm by-products as ruminant feed in Malaysia. Journal of Oil Palm Research, 23, 1029-1035

Liadakis, G. N., Floridis, A., Tzia, C., \& Oreopoulou, V. (1993). Protein isolates with reduced possypol content from screw-pressed cottonseed meal. Journal of Agricultural and Food Chemistry, 41(6), 918-922. http://dx.doi.org/10.1021/jf00030a016.

Liang, L., Cai, S.-y., Gao, M., Chu, X., Pan, X.-y., Gong, K.-K., Xiao, C., Chen, Y., Zhao, Y., Wang, B., \& Sun, K. (2020). Purification of antioxidant peptides of Moringa oleifera seeds and their protective effects on $\mathrm{H}_{2} \mathrm{O}_{2}$ oxidative damaged Chang liver cells. Journal of Functional Foods, 64, 103698. http://dx.doi.org/10.1016/j.jff.2019.103698.

Ma, Y., Xiong, Y., Zhai, J., Zhu, H., \& Dziubla, T. (2010). Fractionation and evaluation of radical scavenging peptides from in vitro digests of buckwheat protein. Food Chemistry, 118(3), 582-588. http://dx.doi. org/10.1016/j.foodchem.2009.05.024. PMid:20352082.

Malaysian Oil Palm Statistics. (2021). Retrieved from https://bepi.mpob. gov.my/index.php/en/?option=com_content\&view=category\&id $=106$

Marmon, S. K., \& Undeland, I. (2013). Effect of alkaline pH-shift processing on in vitro gastrointestinal digestion of herring (Clupea harengus) fillets. Food Chemistry, 138(1), 214-219. http://dx.doi. org/10.1016/j.foodchem.2012.10.035. PMid:23265479.

Maron, D.M., \& Ames, B. N. (1983). Revised methods for Salmonella mutagenicity test. Mutation Research, 113(3-4), 173-215. http:// dx.doi.org/10.1016/0165-1161(83)90010-9. PMid:6341825.

Mitchell, I., \& Combes, R. (1997). In vitro genotoxicity and cell transformation assessment. In J. V. Castell, Gmez- M. J. Lechn (Eds.), In vitro methods in pharmaceutical research (Chap. 14). USA: Academic Press. http://dx.doi.org/10.1016/B978-012163390-5.50015-6.

Mosmann, T. (1983). Rapid coloricmetric assay for cellular growth and survival: Application to proliferation and cytotoxicity assays. Journal of Immunological Methods, 65(1-2), 55-63. http://dx.doi. org/10.1016/0022-1759(83)90303-4. PMid:6606682.

Nasri, M. (2017). Protein hydrolysates and biopeptides: Production, biological activities, and applications in foods and health benefits, a review. Advances in Food and Nutrition Research, 81, 109-159. http://dx.doi.org/10.1016/bs.afnr.2016.10.003. PMid:28317603.

Ng, K. L., \& Mohd Khan, A. (2012). Enzymatic preparation of palm kernel cake protein hydrolysate (PKCPH). International Food Research Journal, 19, 721-725.

Ng, K. L., Ayob, M. K., Said, M., Osman, M. A., \& Ismail, A. (2013). Optimization of enzymatic hydrolysis of palm kernel cake protein (PKCP) for producing hydrolysates with antiradical capacity. Industrial Crops and Products, 43, 725-731. http://dx.doi.org/10.1016/j. indcrop.2012.08.017.

Rajapakse, N., Mendis, E., Jung, W. K., Je, J. Y., \& Kim, S. K. (2005). Purification of a radical scavenging peptide from fermented mussel sauce and its antioxidant properties. Food Research International, 38(2), 175-182. http://dx.doi.org/10.1016/j.foodres.2004.10.002.

Ritchie, H., \& Roser, M. (2021). Palm oil. Our World in Data. Retrieved from https://ourworldindata.org/palm-oil

Rodeiro, I., Cancino, L., González, J. E., Morffi, J., Garrido, G., González, R. M., Nuñez, A., \& Delgado, R. (2006). Evaluation of thegenotoxic potential of Mangifera indica L. extract (Vimag), a new natural product with antioxidant activity. Food and Chemical Toxicology, 44(10), 1707-1713. http://dx.doi.org/10.1016/j.fct.2006.05.009. PMid:16857303.

Sarmadi, B. H., \& Ismail, A. I. (2010). Antioxidative peptides from food proteins: a review. Peptides, 31(10), 1949-1956. http://dx.doi. org/10.1016/j.peptides.2010.06.020. PMid:20600423.

Seyedjavadi, S. S., Khani, S., Zare-Zardini, H., Halabian, R., Goudarzi, M., Khatami, S., Imani Fooladi, A. A., Amani, J., \& RazzaghiAbyaneh, M. (2019). Isolation, functional characterization, and biological properties of MCh-AMP1, a novel antifungal peptide from Matricaria chamomilla L. Chemical Biology \& Drug Design, 93(5), 949-959. http://dx.doi.org/10.1111/cbdd.13500. PMid:30773822.

Sheng, J., Yang, X., Chen, J., Peng, T., Yin, X., Liu, W., Liang, M., Wan, J., \& Yang, X. (2019). Antioxidative effects and mechanism study of bioactive peptides from defatted walnut (Juglans regia L.) meal hydrolysate. Journal of Agricultural and Food Chemistry, 67(12), 33053312. http://dx.doi.org/10.1021/acs.jafc.8b05722. PMid:30817142.

Siddhuraju, P. (2006). The antioxidant activity and free radical scavenging capacity of phenolics of raw and dry heated moth bean (Vigna aconitifolia) (Jacq.) Marechal seed extracts. Food Chemistry, 99(1), 149-157. http://dx.doi.org/10.1016/j.foodchem.2005.07.029.

Singh, N. P., McCoy, M. T., Tice, R. R., \& Schneider, E. L. (1988). A simple technique for quantification of low levels of DNA damage in individual cells. Experimental Cell Research, 175(1), 184-191. http://dx.doi.org/10.1016/0014-4827(88)90265-0. PMid:3345800.

Sonklin, C., Laohakunjit, N., \& Kerdchoechuen, O. (2018). Assessment of antioxidant properties of membrane ultrafiltration peptides from mungbean meal protein hydrolysates. PeerJ, 6, e5337. http://dx.doi. org/10.7717/peerj.5337. PMid:30065890.

Sun, C., Tang, X., Ren, Y., Wang, E., Shi, L., Wu, X., \& Wu, H. (2019). Novel antioxidant peptides purified from mulberry (Morus atropurpurea Roxb.) leaf protein hydrolysates with hemolysis inhibition ability and cellular antioxidant activity. Journal of Agricultural and Food Chemistry, 67(27), 7650-7659. http://dx.doi.org/10.1021/acs. jafc.9b01115. PMid:31241944.

Tong, L. M., Sasaki, S., McClements, D. J., \& Decker, E. A. (2000). Mechanisms of the antioxidant activity of a high molecular weight fraction of whey. Journal of Agricultural and Food Chemistry, 48(5), 1473-1478. http://dx.doi.org/10.1021/jf991342v. PMid:10820045.

Vastag, Z., Popovic, L., Popovic, S., Krimer, V., \& Pericin, D. (2010). Hydrolysis of pumpkin oil cake isolate and free radical scavenging activity of hydrolysates: Influence of temperature, enzyme/substrate ratio and time. Food and Bioproducts Processing, 88(2-3), 277-282. http://dx.doi.org/10.1016/j.fbp.2009.12.003.

Wang, H., Cao, G. H., \& Prior, R. L. (1996). Total antioxidant capacity of fruits. Journal of Agricultural and Food Chemistry, 44(3), 701-705. http://dx.doi.org/10.1021/jf950579y.

Wan-Ibrahim, W. I., Sidik, K., \& Kuppusamy, U. R. (2010). A high antioxidant level of antioxidant in edible plants is associated with genotoxic properties. Food Chemistry, 122(4), 1139-1144. http:// dx.doi.org/10.1016/j.foodchem.2010.03.101.

Wu, J., Sun, B., Luo, X., Zhao, M., Zheng, F., Sun, J., Li, H., Sun, X., \& Huang, M. (2018). Cytoprotective effects of a tripeptide from 
Chinese Baijiu against AAPH-induced oxidative stress in HepG2 cells via Nrf2 signaling. RSC Advances, 8(20), 10898-10906. http:// dx.doi.org/10.1039/C8RA01162A.

Wu, W. U., Hettiarachchy, N. S., \& Qi, M. (1998). Hydrophobicity, solubility and emulsifying properties of soy protein peptides prepared by papain modification and ultrafiltration. Journal of the American Oil Chemists' Society, 75(7), 845-849. http://dx.doi.org/10.1007/ s11746-998-0235-0.

Xu, D.-P., Li, Y., Meng, X., Zhou, T., Zhou, Y., Zheng, J., Zhang, J.-J., \& Li, H.-B. (2017). Natural antioxidants in foods and medicinal plants: Extraction, assessment and resources. International Journal of Molecular Sciences, 18(1), 96. http://dx.doi.org/10.3390/ijms18010096. PMid:28067795.

Yang, R., Li, X., Lin, S., Zhang, Z., \& Chen, F. (2017). Identification of novel peptides from 3 to $10 \mathrm{kDa}$ pine nut (Pinus koraiensis) meal protein, with an exploration of the relationship between their antioxidant activities and secondary structure. Food Chemistry, 219, 311-320. http://dx.doi.org/10.1016/j.foodchem.2016.09.163. PMid:27765232.

Yin, H., Pan, X., Wang, S., Yang, L., \& Sun, G. (2014). Protective effect of wheat peptides against small intestinal damage induced by nonsteroidal anti-inflammatory drugs in rats. Journal of Integrative Agriculture, 13(9), 2019-2027. http://dx.doi.org/10.1016/S20953119(13)60619-X.
Yu, G.-C., Lv, J., He, H., Huang, W., \& Han, Y. (2012). Hepatoprotective effects of corn peptides against carbon tetrachloride-induced liver injury in mice. Journal of Food Biochemistry, 36(4), 458-464. http:// dx.doi.org/10.1111/j.1745-4514.2011.00551.x.

Yust, M., Pedroche, J., Girón-Calle, J., Alaiz, M., Millán, F., \& Vioque, J. (2003). Production of ace inhibitory peptides by digestion of chickpea legumin with alcalase. Food Chemistry, 81(3), 363-369. http://dx.doi.org/10.1016/S0308-8146(02)00431-4.

Zhang, B., Liu, J., Liu, C., Liu, B., Yu, Y., \& Zhang, T. (2020). Bifunctional peptides with antioxidant and angiotensin-converting enzyme inhibitory activity in vitro from egg white hydrolysates. Journal of Food Biochemistry, 44(9), e13347. http://dx.doi.org/10.1111/ jfbc.13347. PMid:32598493.

Zhang, Q., Tong, X., Li, Y., Wang, H., Wang, Z., Qi, B., Sui, X., \& Jiang, L. (2019). Purification and characterization of antioxidant peptides from alcalase-hydrolyzed soybean (Glycine max L.) hydrolysate and their cytoprotective effects in human intestinal Caco-2 cells. Journal of Agricultural and Food Chemistry, 67(20), 5772-5781. http://dx.doi. org/10.1021/acs.jafc.9b01235. PMid:31046268.

Zhou, Y., Jiang, Y., Shi, R., Chen, Z., Li, Z., Wei, Y., \& Zhou, X. (2020). Structural and antioxidant analysis of Tartary buckwheat (Fagopyrum tartaricum Gaertn.) $13 S$ globulin. Journal of the Science of Food and Agriculture, 100(3), 1220-1229. http://dx.doi.org/10.1002/jsfa.10133. PMid:31680256. 